\title{
Üniversite Öğrencilerinin Kosgeb Desteklerine Bakış Açıları Ve Girişimcilik Eğilimleri Üzerine Bir Araştırma: Uşak Üniversitesi Örneği
}

Yılmaz AKYÜZ*

\section{Özet}

Günümüzde bireylerin, girişimcilikleri her açıdan büyük önem kazanmıştır. $\mathrm{Bu}$ nedenle, farklı kurum ve kuruluşlarca eğitim sürecinin farklı kademelerinde girişimcilik eğitimleri verilmektedir. Bunlardan en yaygın olanı da KOSGEB uygulamalı girişimcilik eğitimleridir. Bu kapsamda Yüksek Öğretim Kurumları ve KOSGEB arasında yönetmelikler çerçevesinde yapılan protokoller ile üniversitelerde girişimcilik dersleri verilmektedir. Bu çalışmada, öncelikle üniversite öğrencilerine yönelik girişimcilik eğilimleri ve girişimcilik dersleri üzerine yapılan önceki çalışmalar gözden geçirilmiştir. Daha sonra yükseköğretim kurumları tarafından KOSGEB girişimcilik destek programı kapsamında ders alan Uşak üniversitesi öğrencilerinin KOSGEB desteklerine bakış açıları, girişimcilik eğilimleri ve girişimcilik özellikleri anket yöntemi kullanılarak elde edilen bilgiler ışığında değerlendirilmiştir.

Anahtar Kelimeler: Girişimcilik, Girişimcilik Eğitimi, Yeni Girişimci Desteği, Uşak Üniversitesi

\section{A Research On The Perspectives Kosgeb Support And Trends In Entrepreneurship Of Unıversity Students : An Example Of Uşak University}

\begin{abstract}
Nowadays, entrepreneurship of individuals have gained great importance in everyaspect. Therefore entrepreneurship courses is given of the educational process by different institutions and organisation. The most
\end{abstract}

*Yrd. Doç. Dr., Uşak Üniversitesi, İ̈BF, İşletme Bölümü 
common of which is KOSGEB practical entrepereneurship training. In this context, entrepreneurship courses is given at universities protocols conducted in accordance with the regualtions of between higher education institutions and KOSGEB. In this study, primiraly the previous studies on entrepreneurship courses and trends were reviewd for university students. Then, perspectives of KOSGEB grands, entrepreneurial trends and entrepreneurial characterictics of students of Uşak University take courses from higher education institutions with in the scope of KOSGEB entrepreneurship support programme were evaluated in the light of the information obtained using survey method.

Keywords: Enterpreneurship, Entrepreneurship Education, New Entrepreneurship Support, Uşak University

\section{Giriș}

Günümüzde yaşanan hızlı değişimler ve bilimsel yenilikler ile teknolojide yaşanan gelişmelere paralel olarak girişimcinin ve girişimciliğin ekonomik değeri ve toplumdaki önemi oldukça artmıştır. Bu süreçte bireye dayalı girişimcilik ön plana çıkmış ve girişimcinin entelektüel üretkenlik yeteneği ön plana çıkmıştır. Buna bağlı olarak; 2000'li yıllarda girişimcilerinin sahip olması gereken özellikler konusunda farklı çalışmalar ve bakış açıları gündeme gelmektedir.

Girişimcilik sayesinde yeni iş olanakları sağlanırken, ekonomilerde meydana gelen işsizlik sorunun çözümünde de önemli faydalar sağlanmaktadır. Bunların yanı sıra farklı ve stratejik düşünce yapısına sahip girişimciler sayesinde piyasalara yeni ürün ve hizmet sunulmasında girişimciliğin rolü büyüktür. Buradan yola çıkarak girişimciliğin iş ve toplum hayatının önemli dinamiklerinden birisi olduğunu söyleyebiliriz.

Girişimciliğin doğuştan gelen bir yetenek mi ? Yoksa sonradan eğitimle kazanılan bir olgu mu olduğu tartışma konusu haline gelmiştir. Girişimciliğin günümüzde bir disiplin olarak değerlendirilmesi, girişimciliğin doğuştan gelen bir yetenek olduğu konusunda ortaya çıkan görüş, zaman içerisinde değişiklik göstererek girişimcilik eğitimi yapılabileceği görüşü kabul görmeye başlamıştır (Tağraf, Halis, 2008: 92) .

Ülkemizin kalkınması açısından girişimcilere büyük görevler düşmektedir. Girişimciliğin gelişip büyümesi için de eğitime ve üniversitelere büyük görevler düşmektedir. Üniversiteler bu girişimciliği harekete geçirebilmek için girişimciliğin ayrı bir ders olarak okutulması yanında bunun sürdürülebilir ve uygulanabilir olmasını sağlamalıdır. Bu amaç doğrultusunda genç bireylerin; iş yaşamının ve toplumun ihtiyaçlarına göre eğitim görmeleri ve bu eğitim gördükleri, alanlarda istihdam edilmeleri 
ve kendi mesleki alanlarında girişimci bir ruha sahip olmaları, ülke ekonomisi açısından oldukça kritik ve büyük önem taşımaktadır. (Arıkan, 2004:1, Klofsten 2000:337-344), Bu nedenle girişimciliğin gelişmesinde en önemli faktörlerden birisi de girişimcilik konusunda verilen eğitimlerdir. Verilen girişimcilik eğitimleri ile girişimcilik faaliyetleri arasında önemli bir ilişkinin olduğuna dair birçok araştırma bulunmaktadır (Bozkurt, 2011: 1). Bu bağlamda bu çalışmada yükseköğretim kurumları tarafından KOSGEB girişimcilik destek programı kapsamında verilen seçmeli uygulamalı girişimcilik dersleri alan üniversite öğrencilerinin KOSGEB desteklerine bakış açıları, girişimcilik eğilimleri ve girişimcilik özelliklerini araştırmak üzere bir anket araştırması ile Uşak üniversitesi öğrencilerinin girişimciliğe karşı tutumları değerlendirilmektedir.

\section{Literatür}

Yelkikalan, N., Akatay, A., vd. , (2010) çalışmalarında Dünya ve Türkiye üniversitelerinde verilen girişimcilik eğitiminin karşılaştırmalı bir analizini yapmışlardır. Araştırma sonuçlarına göre, Türkiye'de girişimcilik eğitiminin genellikle ön lisans düzeyinde yoğun olarak verildiği, dünyada ise durumun tam tersi olduğu sonucuna ulaşmışlardır.

Çetinkaya Bozkurt, Ö., (2011) Girişimcilik eğitiminin Dünya ve Türkiye açısından değerlendirildiği çalışmasında girişimcilik eğitiminin önemine vurgu yapmıştır. Ayrıca girişimci adayların kişisel özelliklerinin eğitime başlamadan önce tespit edilmesi ve gerekli olan eğitimin bu doğrultuda verilmesi gerektiği üzerinde durmuştur.

Öktem, M.K.; Aydın, M., Ekinci, S.,(2007)Türkiye'de girişimciliğin geliştirilmesinde KOSGEB'in rolünün araştırıldığı çalışmalarında KOSGEB'in araştırma kapsamındaki faaliyetlerinde saptanan eksikliklerin giderilmesi halinde KOSGEB'in Türkiye'de girişimciliği daha etkin ve verimli bir şekilde arttırabileceği sonucuna ulaşmışlardır. Bu bağlamda KOSGEB'in Türkiye'de girişimciliği arttırma yönünde büyük öneme sahip olduğunu söyleyebiliriz.

Wilson, K.,(2008) çalışmasında inovasyon ve ekonomik gelişmenin girişimci ruhu kazanmış gerekli bilgi ve donanıma sahip liderler tarafından elde edileceği üzerinde durmuş ve girişimcilik eğitiminin bu bilgi ve donanımı geleceğin liderlerine kazandırmada en önemli olgulardan birisi olduğu üzerinde durmuştur.

Huber, L., vd (2012), çalışmalarında girişimcilik eğitiminin erken yaşlarda verilmesinin etkisini ölçmeye çalıştıkları çalışmalarında verilen eğitimin bilişsel girişimcilik becerilerine herhangi bir etkisinin olmadığını, ancak bilişsel olmayan girişimcilik becerilerine olumlu etkisi olduğu 
sonucuna ulaşmışlar ve bilişsel olmayan girişimcilik becerilerinin en iyi erken yaşlarda kazanıldığı sonucuna ulaşmışlardır.

Leino, J.S., vd.,(2009) çalışmalarında Finlandiya'da girişimcilik eğitimi veren eğitimcilerin girişimcilik konusunda bildiklerinin hala bir süreç kapsamında olduğu ve girişimcilik eğitiminin güçlendirilmesi konusunda çok sınırlı kaldıkları yönünde sonuçlara ulaşmışlardır.

Akın A.; Zor İ.,(2009) Yapılan bu çalışmada öncelikle, işletmecilik eğitiminin bireyin girişimci niteliklerinin geliştirilmesine etkilerinin araştırıldığı bu çalışmada işletmecilik eğitimi veren eğitim programlarının içeriği disipline olmuş şekliyle ortaya konmakta, daha sonra, üniversitelerde yapılan araştırmaların bulguları istatistiksel analize tabi tutulmuştur. Ayrıca çalışmada, bireyin sahip olduğu girişimcilik yeteneklerinin, üniversitelerdeki işletmecilik eğitimi ile sonradan geliştirilmesine yönelik öğrenci algılamaları araştırılmıştır.

Hiscock vd., (2004) üniversite öğrencilerinde girişimci davranışları oluşturmayı amaçlayan değişkenlerin tespiti üzerine bir çalışma yapılarak sonuç ve öneriler sunulmuştur.

Uygun M.,vd (2012) Genç girişimci adayların girişimcilik eğilimi ve girişimcilik özellikleri arasındaki ilişkilerin araştırıldığı bu çalışma Aksaray Üniversitesi'nde okuyan genç girişimcilerin girişimcilik eğilimi ile girişimci kişilik özellikleri ve kişisel-özgeçmiş faktörlerinden oluşan kişisel özellikleri arasındaki ilişkilerin incelenmesi amacıyla tasarlanmıştır. Toplanan veriler Ki-Kare ve Çok Değişkenli Varyans Analizi (MANOVA) ile değerlendirilmiştir. Araştırma ile genç girişimci adaylarının girişimcilik eğilimleri ile kişisel ve özgeçmiş faktörleri arasında anlamlı ilişkiler olduğunu ortaya koymuştur.

Koh (1996), Hong Kong'daki lisansüstü öğrenciler üzerinde risk alma eğilimi, belirsizliğe katlanma ve yenilikçilik özelliklerinin saptanmasına yönelik bir araştırma gerçekleştirmiştir. Yapılan araştırmanın sonucunda, risk alma eğilimi, belirsizliğe katlanma ve yenilikçilik özelliklerinin girişimci eğilime sahip olan öğrencilerde, sahip olmayan öğrencilere göre daha fazla olduğu sonucuna varmıştır.

Seçkin Halaç D., Bulut Ç., (2012) Yapılan bu çalışmada Geleceğin girişimcileri olarak üniversite öğrencileri birer ulusal kaynak olarak görülmesi ve girişimcilik eğilimlerini arttırmaya yönelik her çabanın tüm ülke için önemi göz ardı edilmemesi gerekliliği kavramsal çerçeveden bakılmıştır. Bu bağlamda, bu çalışmada ülke olarak girişimcilikte ne durumda olduğumuz üzerinde durulmuştur.

Yılmaz E., Sünbül A.M. (2009) Bu çalışmada üniversite öğrencilerinin girişimciliklerini ölçebilecek güvenilir ve geçerli bir ölçme aracı 
geliştirilmeye çalışılmıştır. Araştırmanın çalışma grubunu Selçuk Üniversitesinin farklı bölümlerinde okuyan öğrenciler oluşturmuştur. Ölçeğin yap1 geçerliliğine ilişkin bulgular faktör analizi yöntemi ile sağlanmıştır. Temel bileşenler analizlerine dayalı olarak ölçeğin maddelerinin tek bir faktörde toplandığı görülmüştür. Ölçek toplam puanlarında, öğrencilerin cinsiyet değişkenine göre manidar farklar bulunamamıştır.

\section{Girişimcilik Tanımı ve Önemi}

"Girişimci" ve "Girişimcilik" kavramlarıyla ilgili literatürde pek çok bilim insanının tanımlamalarını görmek mümkündür. Girişimci kavramının, Latince'de intare kökünden geldiği belirtilmektedir. İngilizce'de entrepreneur olarak kullanılan girişimci enter (giriş) ve pre (ilk) kelime köklerinden gelmekte ve entrepreneur yani ilk başlayan anlamına gelmektedir (Korkmaz, 2000:12-20). Dolayısıyla, girişimci; mal ve hizmet üretmek amacıyla, pazardaki fırsatları değerlendiren, sermaye, doğal kaynaklar ve emek gibi üretim faktörlerini bir araya getirerek riski üstlenen kişidir Yaygın olarak kullanılan bir tanıma göre Girişimcilik ise; emek, teknoloji, sermaye ve doğal kaynaklar olarak sayılan üretim faktörlerini bir araya getirerek mal veya hizmet üretme eylemlerini kapsar(Muellerand Thomas, 2000:5, Müftüoğlu ve Durukan (2004, s.15).

Bu tanımlamayı daha da genişletecek olursak, girişimci: (Akdemir, 2004: 25) “ Bilgiyi temel alarak, genel eğilimlere ve kendisine uygun bir alanı seçerek ve/veya bilgisini girişimciliğe konu ederek, herhangi bir finansman yöntemi kullanıp, dünyalı tüm insanların yararı için mal ve hizmet üretmek amacıyla işletme açıp ekonomik gereksinimini, ekonomik zenginliğini, bağımsızlığını, sosyal prestijini, kendini kabul ettirmeyi ve kendisini aşmayı, açtığ 1 işletmesinde sürdüren, sürdürme arzusunda ve çabasında olan herkes girişimcidir"

Yapılan çok farklı girişimcilik tanımlarının ortak noktalarını şu şekilde sıralamak mümkündür: (Yurtseven, 2007: 60);

- İnisiyatif almak,

- Sosyo ekonomik işleyişleri, değerli yapı ve kaynaklara çevirmek için, organize etmek ya da yeniden organize etmek,

- Alınacak risk karşısında başarısızlığı kabul etmek

Girişimciler günümüzde ekonomik yaşamın dinamosu haline gelmişlerdir. İktisadi hayatta girişimciler yeni iş sahaları açarak, icat böylelikle ekonomik büyümeye yardımcı olurlar. Genel ekonomik düzen içerisinde girişimcilere hayatın her aşamasında rastlamak mümkündür. 
Uşak Üniversitesi Sosyal Bilimler Dergisi

$2013,6 / 3$

Y. AKYÜZ

Manavdan, tamirciye hatta büyük holdinglere kadar çok çeşitli girişimcilik örnekleri ile ekonomilerin itici gücü ve iktisadi gelişmenin dinamiği olarak iş hayatına önemli katkılar sağlamaktadırlar (Tekin, 2009: 2).

Girişimcilik eğitimleri ile bireylerdeki ortaya çıkmamış yetenekler açığa çıkartılarak ülke ekonomisine daha fazla girişimci kazandırılmakta, girişimcilerin başka mesleklerde uğraşmalarının önüne geçilmektedir. Böylelikle ülke ekonomilerinde genel sermayenin boşa harcanması önlenerek toplumsal kaynakların daha etkin bir şekilde kullanımı sağlanmaktadır (Filiz, http://www.biymed.com ).

\section{KOSGEB Girişimcilik Destek Programı}

Bu programın amacı, ekonomik kalkınma ve istihdam sorunlarının çözümünün temel faktörü olan girişimciliğin desteklenmesi, yaygınlaştırılması ve başarılı işletmelerin kurulmasını sağlamaktır. Bu program, küçük ve orta ölçekli işletmelere, girişimcilere ve işletici kuruluşlara yönelik olarak KOSGEB tarafından uygulanacak Girişimcilik Destek Programına ilişkin esasları kapsar. Destek programının kapsamı, Uygulamalı Girişimcilik Eğitimi, Yeni Girişimci Desteği ve İşGEM Desteği olmak üzere üç alt programdan oluşmaktadır. (www.kosgeb.gov.tr/ Girişimcilik Destek Programı Uygulama Esasları 20.08.2013). Konumuz gereği burada Uygulamalı Girişimcilik Eğitimi, Yeni Girişimci Desteği üzerinde durulacaktır. Girişimcilik Destek Programı uygulama esaslarını kısaca şu şekilde özetlemek mümkündür.

\subsection{Uygulamalı Girişimcilik Eğitimi}

Girişimciliğin gelişiminde en önemli faktörlerden biri de bu konuda verilen eğitimlerin yaygınlaştırılması ve kişilerin girişimcilik özelliklerinin geliştirilmesidir. Uygulamalı Girişimcilik Eğitimlerinin hedef kitlesi kendi işini kurmak isteyen gerçek kişiler olup, eğitimler genel katılıma açı olarak düzenlenebileceği gibi, genç girişimci, kadın girişimci ve yükseköğretim kurumları öğrencileri gibi belirli bir hedef kitle grubuna yönelik olarak da yapılabilir. Uygulamalı Girişimcilik Eğitiminin süresi, 24 (yirmi dört) saati atölye çalışmaları olmak üzere toplam 70 (yetmiş) saattir. Sektörel ve yerel düzeyde belirlenen ihtiyaçlar doğrultusunda ilave eğitimler de eklenebilmektedir. KOSGEB tarafından gerçekleştirilen Uygulamalı Girişimcilik Eğitimlerinde ilave eğitimlerin süresi 15 (on beş) saati aşamaz ve Yükseköğretim kurumları tarafından örgün eğitim kapsamında verilen 
Uşak Üniversitesi Sosyal Bilimler Dergisi

$2013,6 / 3$

Y. AKYÜZ

girişimcilik dersinin bir akademik yıl içerisinde en az 56 (elli altı) saat olması gerekmektedir ${ }^{1}$.

Uygulamalı Girişimcilik Eğitimi Modelleri

Uygulamalı Girişimcilik Eğitimleri, girişimcilik kültürünü yaygınlaştırmak ve girişimcilerin bir iş planına dayalı olarak kuracakları işletmelerin başarı düzeylerini artırmak amacıyla düzenlenir. Bu kapsamda düzenlenecek eğitimler(kosgeb.gov.tr).;

-KOSGEB Birimleri tarafından düzenlenen Uygulamalı Girişimcilik Eğitimleri,

-Ulusal veya uluslararası projeler kapsamında, KOSGEB tarafından yürütülen Uygulamalı Girişimcilik Eğitimleri,

-Kurum ve kuruluşlar tarafından düzenlenen Uygulamalı

Girişimcilik Eğitimleri,

-Yükseköğretim kurumları tarafından örgün eğitim kapsamında verilen girişimcilik eğitimi dersleridir. Bu çerçevede KOSGEB-Uşak Üniversitesi Girişimcilik Eğitim Protokolü imzalanmış ve uygulamaya geçilmiştir

\section{Uşak Üniversitesi -KOSGEB Girişimcilik Eğitim Protokolü}

KOSGEB Yeni Girişimci desteklerinden yararlanabilmek için Katılım Belgesi almak zorunludur. Bu amaçla, Yükseköğretim kurumları tarafından örgün eğitim kapsamında verilen girişimcilik dersinin Uygulamalı Girişimcilik Eğitimi kapsamında değerlendirilmesi için ilgili yükseköğretim kurumunun Başkanlıktan uygunluk onayı alması gerekir. Bu kapsamda Uşak üniversitesi 2012-2013 Egitim Öğretim yılı Bahar Döneminden itibaren uygulanmak üzere lisans öğrencilerine yönelik olarak (seçmeli) Uygulamalı Girişimcilik Dersi yapılan protokoller ile uygunluk onayı alınarak müfredata konulmuştur. Katılım Belgesi verebilmek için Uygulamalı Girişimcilik dersi 14 hafta boyunca girişimcilik ve is kurma üzerine toplam 56 saatlik eğitim ve atölye çalışmasından oluşan bir kapsamda yerine getirilmektedir. Böylece Uygulamalı Girişimcilik Eğitimlerine katılarak Katılım Belgesi alanlar, KOSGEB Yeni Girişimci Desteğine başvuru yapma hakkını elde etmiş olacaklardır. Dersin amacı; ortaöğretim sonrası üniversite öğrencilerinin kariyer planlaması yaptığı bir dönemde, girişimciliği önlerine bir seçenek olarak sunarak gençleri kendi isini kurmaya yöneltmek ve bu kurumlarda girişimcilik kültürünün yaygınlaşmasını sağlamaktır. Bu programda;

KOSGEB 06/12/2012 tarih ve 2012/19 No'lu İcra Komitesi Kararı ve 15/03/2013 tarih ve 3757 sayılı OLUR ile değişiklik kabul edilmiştir. Üniversiteler tarafindan örgün eğitim kapsamında verilen girişimcilik dersinin bir akademik yıl içerisinde en az 56 (ellialtı) saat olmast gerekmektedir. 
katılımcılara iş fikri geliştirme, pazar araştırması, iş planı, pazarlama planı, proje ve proje yönetimi gibi konularda bilgi verilerek, katılımcıların ileride kuracakları işletmelerin başarı oranlarının artıılması hedeflenmektedir. Bu dersi Uşak Üniversitesi son sınıf öğrencileri seçmeli ders olarak seçerek verilen haklardan yararlanabilmektedir. Bununla birlikte, üniversitelerde, girişimcilik potansiyelini geliştirmeyi hedefleyen eğitimler yalnızca derslerle sınırlı kalmamakta, farklı girişimcilik etkinlikleriyle mevcut birikim daha da geliştirilmeye çalışılmaktadır.

\subsection{KOSGEB Yeni Girişimci Desteği}

Destek programı kapsamında Uygulamalı Girişimcilik Eğitimlerine katılarak Katılım Belgesi alanlar, KOSGEB Yeni Girişimci Desteğine başvuru yapma hakkı kazanırlar. Yeni Girişimci Desteğinden; program kapsamında gerçekleştirilen bir Uygulamalı Girişimcilik Eğitimini, tamamlayarak, eğitime veya programa katıldığını belgeleyen ve eğitimi veya programı tamamladıktan sonra işletmesini kuran girişimciler yararlanabilir.

Destekten yararlanma koşulları ve yeni girişimci destek unsurları:

-Yeni Girişimci Desteğinden yararlanmak isteyen işletmelerin KOSGEB veri tabanında yer alması zorunludur.

-Girişimcilerin kurmuş oldukları işletmelerdeki kurucu ortak olarak payları en az \% 30 (otuz) olmalıdır.

- İşletmenin bu destekten yararlanabilmesi için, destek başvuru tarihi itibari ile son iki yıl içinde kurulmuş olması ve girişimcinin daha önce bu destekten faydalanmamış olması şartı aranır. Birden fazla girişimcinin aynı işletmede ortak olması durumunda, işletme bu destekten yalnızca bir defa faydalanabilir.

-Destek başvurusunun, KOSGEB Birimi tarafından bilgi, belge ve şekil yönünden ön değerlendirmesinin ardından, iş planı kurula sunulur. Kurulda, bütçe olanakları dikkate alınarak, yenilikçi, yeni teknik ve teknoloji kullanabilecek, katma değeri yüksek veya ihraç edilebilecek ürün veya hizmet üretebilecek işletmeler, imalat sektöründe kurulan işletmeler ve mesleki ve teknik eğitim mezunu ve mesleki yeterlilik belgesine sahip olanları istihdam eden işletmelerin iş planları öncelikli olarak değerlendirilir(www.kosgeb.gov.tr/Pages/UI/Destekler.aspx?ref=8). 
Tablo 1:Yeni Girişimci Desteği Destek Unsurları

\begin{tabular}{|c|c|c|c|c|}
\hline DESTEK UNSURU & ÖDEME & $\begin{array}{l}\text { ÜST } \\
\text { LIMIT } \\
\text { (TL) }\end{array}$ & $\begin{array}{c}\text { DESTEK } \\
\text { ORANI } \\
\text { (1. ve } 2 \text {. Bölge) }\end{array}$ & $\begin{array}{c}\text { DESTEK ORANI } \\
\text { (3. 4.5.ve } 6 . \\
\text { Bölge) }\end{array}$ \\
\hline $\begin{array}{c}\text { İşletme Kuruluş } \\
\text { Desteği }\end{array}$ & $\begin{array}{c}\text { Geri } \\
\text { ödemesiz }\end{array}$ & 5.000 & \multirow{4}{*}{$\begin{array}{c}\text { \%60 } \\
\text { (Kadın veya } \\
\text { özürlü } \\
\text { girişimci:\%70) }\end{array}$} & \multirow{4}{*}{$\begin{array}{c}\text { \%70 } \\
\text { (Kadın veya } \\
\text { özürlü } \\
\text { girişimci:\%80) }\end{array}$} \\
\hline $\begin{array}{l}\text { Kuruluş Dönemi } \\
\text { Makine, Teçhizat ve } \\
\text { Ofis Donanım } \\
\text { Desteği }\end{array}$ & $\begin{array}{c}\text { Geri } \\
\text { ödemesiz }\end{array}$ & 10.000 & & \\
\hline $\begin{array}{c}\text { İşletme Giderleri } \\
\text { Desteği }\end{array}$ & $\begin{array}{c}\text { Geri } \\
\text { ödemesiz }\end{array}$ & 12.000 & & \\
\hline Sabit Yatırım Desteği & $\begin{array}{c}\text { Geri } \\
\text { Ödemeli }\end{array}$ & 70.000 & & \\
\hline
\end{tabular}

Kaynak:www.kosgeb.gov.tr/Pages/UI/Destekler.aspx?ref=8

a) İşletme kuruluş desteği: İşletme kuruluş giderleri için geri ödemesiz olarak verilen bu desteğin üst limiti 3.000 (üç bin) TL olup, destekleme oranı 1. ve 2. Bölgeler için \% 60 (altmış), girişimcinin kadın veya özürlü olması halinde \% 70 (yetmiş) olup; 3., 4., 5. ve 6. Bölgelerde bu oran \% 70 (yetmiş), girişimcinin kadın veya özürlü olması halinde \% 80 (seksen) olarak uygulanir.

b) Kuruluş dönemi makine, teçhizat, yazılım ve ofis donanım desteği: İşletmenin kuruluş tarihinden itibaren 12 (on iki) ay içinde satın alınan/alınacak makine, teçhizat, yazılım ve ofis donanımı için geri ödemesiz olarak verilen bu desteğin üst limiti 15.000 (on beş bin) TL ve destekleme oranı 1. ve 2. Bölgeler için \% 60 (altmış), girişimcinin kadın veya özürlü olması halinde \% 70 (yetmiş) olup; 3., 4., 5. ve 6. Bölgelerde bu oran $\% 70$ (yetmiş), girişimcinin kadın veya özürlü olması halinde \% 80 (seksen) olarak uygulanir.

c) İşletme giderleri desteği: Desteğin başlangıç tarihinden itibaren 24 (yirmi dört) ay içinde gerçekleşen işletme giderlerine yönelik geri ödemesiz olarak ödenecek desteğin üst limiti her ay için 1.000 (bin) TL olmak üzere, toplam 12.000 (on iki bin) TL ve destekleme oranı 1. ve 2 . 
Uşak Üniversitesi Sosyal Bilimler Dergisi

$2013,6 / 3$

Y. AKYÜZ

Bölgeler için \% 60 (altmış), girişimcinin kadın veya özürlü olması halinde \% 70 (yetmiş) olup; 3., 4., 5. ve 6. Bölgelerde bu oran \% 70 (yetmiş̧), girişimcinin kadın veya özürlü olması halinde \% 80 (seksen) olarak uygulanır. Personel net ücretleri, -İşyeri kirası, elektrik, su, 1sıtma, telekomünikasyon, işyerinde üretim amaçlı kullanılan makine ve teçhizata ait yakıt giderleri işletme giderleri olarak sayllır

d) Sabit yatırım desteği:

Desteğin başlangıç tarihinden itibaren 24 (yirmi dört) ay içinde satın alınacak, makine ve teçhizat için teminat karşılığı geri ödemeli olarak verilen bu desteğin üst limiti 70.000 (yetmiş bin) TL'dir. Sabit Yatırım Desteği kapsamında destek geri ödemesi yapılacak geri ödemeler, desteğin başlangıç tarihinden sonra 24 (yirmi dört) ayı ödemesiz olmak üzere, üçer aylık dönemler halinde 8 (sekiz) eşit taksitte yapılır. Geri ödemeli desteklerde faiz veya komisyon uygulanmamaktadır.

\section{3.Öğrencilerin KOSGEB Destekleri ve Girişimciliğe Bakış Açılarının Değerlendirilmesine Yönelik Bir Araştırma}

\section{Araştırmanın Amacı, Kapsamı ve Yöntemi}

Yapılan bu araştırmanın amacı; üniversite öğrencilerinin KOSGEB destekleri ve girişimciliğe olan bakış açılarını değerlendirmektir. Çalışmada anket yöntemi uygulanmıştır. Bu araştırma için kullanılan anket soruları genel kabul görmüş sorular yanında Uygun M.,vd (2012:150) ve Öktem, M.K.; Aydın, M., Ekinci, S., (2007:50-70) çalışmalarından yararlanılarak oluşturulmuştur. Anket soruları öncelikle 35 öğrenci üzerinde pilot bir çalışma yapılarak uygulanmıştır. Yapılan bu pilot çalışmada ölçeğin güvenilirlik katsayısı (Cronbach'salpha) 0.760 çıkmıştır.

Ölçeğin güvenilirliği $0.60 \leq \alpha \leq 0.80$ arasında olduğu için ölçek oldukça güvenilirdir denilmektedir (Kalaycı, 2010:405).

Kullanılan bu anket Uşak Üniversitesi İ̈BF son sınıf öğrencilerini kapsamaktadır. Bu kapsamda 137 öğrenciyle yüz yüze görüşülerek anket uygulaması yapılmıştır.

Üniversite öğrencilerine uygulanan anket formu dört kısımdan meydana gelmektedir. Birinci kısımda demografik sorular, ikinci kısımda girişimci özelliklerinden, girişimciliğe yönlendiren özellikleri, üçüncü kısımda dünyadaki girişimcilik ruhu ile Türkiye'deki girişimcilik ruhunun kıyaslanması, dördüncü kısımda ise KOSGEB ile ilgili 5'li likert ölçekli sorulardan oluşmaktadır. Anket sonuçları ise SPSS 16 programına girilip, frekans dağılımları elde edilerek öğrencilerin bakış açıları ve eğilimleri ortaya konmaya çalışılmıştır. 
Uşak Üniversitesi Sosyal Bilimler Dergisi

$2013,6 / 3$

Y. AKYÜZ

\section{Araştırma Bulgularının Değerlendirilmesi} verilmiştir.

$\mathrm{Bu}$ bölümde yapılan çalışmadan elde edilen sonuçlara yer

Ankete katılan öğrencilerin \%65.9'unu bayan öğrenciler , \%52.3'ü 1922 yaş aralığı, \%86'sını işletme bölümü, öğrencilerin baba mesleğinin ise \% 38.8' inin emekli olduğu, ailenin gelirine bakıldığında \% 35,6'lık kısmının 250-1000 TL arasında olduğu, büyüdükleri bölgenin \% 46'sının Ege Bölgesi olduğu, yaşanılan şehrin \% 32.1'i büyük şehir olduğu, ve mezun olduktan sonra \% 56,9'unun ise devlet memuru olmayı istediği görülmektedir.

Araştırmaya katılan üniversite öğrencilerin demografik bilgileri Tablo 2.'de görüldüğü gibidir.

Tablo 2: Katılımcı Özellikleri

\begin{tabular}{|c|c|c|c|c|c|}
\hline \multirow{3}{*}{ Yaş } & & Yüzde & & & Yüzde \\
\hline & $19-22$ & 52.3 & \multirow[t]{2}{*}{ Cinsiyet } & Erkek & 34.1 \\
\hline & 23-ve Üzeri & 47.8 & & Bayan & 65.9 \\
\hline \multirow{2}{*}{$\begin{array}{l}\text { Okuduğu- } \\
\text { nuz Bölüm }\end{array}$} & İşletme & 86.1 & \multirow{5}{*}{$\begin{array}{c}\text { Ailenin } \\
\text { Aylik } \\
\text { Geliri }\end{array}$} & $250-1000$ & 35,6 \\
\hline & Maliye & 13.9 & & $1001-1750$ & 34,1 \\
\hline \multirow{7}{*}{$\begin{array}{l}\text { Baba } \\
\text { Mesleği }\end{array}$} & Memur & 11,9 & & $1751-2500$ & 14,8 \\
\hline & Emekli & 38,8 & & $2501-3250$ & 6,7 \\
\hline & Özel Sektör & 9,0 & & 3251 Üzeri & 8,9 \\
\hline & Esnaf-Tüccar & 10,4 & \multirow{7}{*}{$\begin{array}{l}\text { Büyüdü } \\
\text { gü̈nüz } \\
\text { Bölge }\end{array}$} & Marmara & 14,6 \\
\hline & Sanayici & 1,5 & & Ege & 46,0 \\
\hline & Serbest Meslek & 9,7 & & Akdeniz & 13,1 \\
\hline & Diğer & 18,7 & & Karadeniz & 2,9 \\
\hline \multirow[t]{5}{*}{$\begin{array}{l}\text { Yaşanılan } \\
\text { Şehir }\end{array}$} & $\begin{array}{l}\text { Orta } \\
\text { Büyüklükte } \\
\text { Şehir }\end{array}$ & 16,1 & & $\begin{array}{l}\text { Güney } \\
\text { Doğu } \\
\text { Anadolu }\end{array}$ & 8,8 \\
\hline & Küçük Şehir & 22,6 & & $\begin{array}{l}\text { Doğu } \\
\text { Anadolu }\end{array}$ & 5,8 \\
\hline & Köy & 13,9 & & İç Anadolu & 8,8 \\
\hline & Kasaba & 15,3 & & & \\
\hline & Büyük Şehir & 32,1 & & & \\
\hline \multirow{4}{*}{$\begin{array}{l}\text { Mezun } \\
\text { Olduktan } \\
\text { Sonra } \\
\text { Yapmayı }\end{array}$} & $\begin{array}{l}\text { Devlet } \\
\text { Memurluğu }\end{array}$ & 56,9 & & & \\
\hline & Akademisyen & 8,0 & & & \\
\hline & Özel Sektör & 18,2 & & & \\
\hline & Kendi İssini & 12,4 & & & \\
\hline
\end{tabular}


Uşak Üniversitesi Sosyal Bilimler Dergisi

$2013,6 / 3$

Y. AKYÜZ

\begin{tabular}{|l|l|c|l|l|l|}
\hline \multirow{2}{*}{$\begin{array}{l}\text { Düşşünülen } \\
\text { İ }\end{array}$} & Kurmak & & & & \\
\cline { 2 - 6 } & $\begin{array}{l}\text { Baba Mesleği } \\
\text { Sürdürmek }\end{array}$ & 1,5 & & & \\
\cline { 2 - 6 } & Diğer & 2,9 & & & \\
\hline
\end{tabular}

Üniversite öğrencilerinin çoğunluğu yenilikçilik, liderlik, otokontrol, risk alma, bağımsız olma, kendine güven, iyimserlik ve başarı ihtiyacına katıldığını belirtmektedir.

Üniversite öğrencilerinin girişimci özelliklerinden, girişimciliğe yönlendiren özellikleri hakkında 5'li likert ölçekli sorular ise tablo 3'te görüldüğü gibidir.

Tablo 3: Girişimci Özelliklerinden, Girişimciliğe Yönlendiren Özellikler

\begin{tabular}{|c|c|c|c|}
\hline & & Frekans & Yüzde \\
\hline \multirow[t]{5}{*}{ Yenilikçilik } & Kesinlikle Katılmıyorum & 5 & 3,6 \\
\hline & Katılmiyorum & 2 & 1,5 \\
\hline & Kararsızım & 10 & 7,3 \\
\hline & Katıliyorum & 49 & 35,8 \\
\hline & Kesinlikle Katıliyorum & 71 & 51,8 \\
\hline \multirow[t]{5}{*}{ Liderlik } & Kesinlikle Katılmıyorum & 3 & 2,2 \\
\hline & Katılmiyorum & 5 & 3,6 \\
\hline & Kararsızım & 12 & 8,8 \\
\hline & Katıliyorum & 46 & 33,6 \\
\hline & Kesinlikle Katılıyorum & 71 & 51,8 \\
\hline \multirow[t]{5}{*}{ Otokontrol } & Kesinlikle Katılmıyorum & 3 & 2,2 \\
\hline & Katılmıyorum & 2 & 1,5 \\
\hline & Kararsızım & 17 & 12,4 \\
\hline & Katıliyorum & 65 & 47,4 \\
\hline & Kesinlikle Katıllyorum & 50 & 36,5 \\
\hline \multirow[t]{5}{*}{ Risk Alma } & Kesinlikle Katılmıyorum & 4 & 2,9 \\
\hline & Katılmiyorum & 1 & , 7 \\
\hline & Kararsızım & 14 & 10,2 \\
\hline & Katıliyorum & 45 & 32,8 \\
\hline & Kesinlikle Katılıyorum & 73 & 53,3 \\
\hline \multirow[t]{4}{*}{ Bağımsız Olma } & Kesinlikle Katılmıyorum & 6 & 4,4 \\
\hline & Katılmiyorum & 4 & 2,9 \\
\hline & Kararsızım & 24 & 17,5 \\
\hline & Katıliyorum & 43 & 31,4 \\
\hline
\end{tabular}


Uşak Üniversitesi Sosyal Bilimler Dergisi

$2013,6 / 3$

Y. AKYÜZ

\begin{tabular}{|c|c|c|c|}
\hline & Kesinlikle Katıliyorum & 60 & 43,8 \\
\hline \multirow[t]{5}{*}{ Kendine Güven } & Kesinlikle Katılmıyorum & 5 & 3,6 \\
\hline & Katılmiyorum & 1 & 7 \\
\hline & Kararsızım & 6 & 4,4 \\
\hline & Katıliyorum & 33 & 24,1 \\
\hline & Kesinlikle Katıliyorum & 92 & 67,2 \\
\hline \multirow[t]{5}{*}{ İyimserlik } & Kesinlikle Katılmıyorum & 4 & 2,9 \\
\hline & Katılmiyorum & 19 & 13,9 \\
\hline & Kararsızım & 29 & 21,2 \\
\hline & Katıliyorum & 40 & 29,2 \\
\hline & Kesinlikle Katıliyorum & 45 & 32,8 \\
\hline \multirow[t]{5}{*}{ Başarı İhtiyacı } & Kesinlikle Katılmıyorum & 5 & 3,6 \\
\hline & Katılmiyorum & 2 & 1,5 \\
\hline & Kararsızım & 17 & 12,4 \\
\hline & Katıliyorum & 50 & 36,5 \\
\hline & Kesinlikle Katılıyorum & 63 & 46,0 \\
\hline
\end{tabular}

Öğrenciler dünyadaki girişimcilik ruhu ile Türkiye'deki girişimcilik ruhu kıyaslamasında \%75'lik kısmı dünya ile kıyaslandığında eğitim yönünden eksiklerin bulunduğu ve kültür farklılığının bulunduğunu belirtmektedirler. Bu duruma ilişkin görüşler Tablo 4 'te görülmektedir.

Tablo 4 : Dünyadaki Girişimcilik Düzeyi ile Türkiye'deki Girişimcilik Düzeyi Kıyaslanması

\begin{tabular}{|c|c|c|c|}
\hline & & Frekans & Yüzde \\
\hline \multirow{5}{*}{$\begin{array}{l}\text { Dünyaya Göre Türkiye Alt } \\
\text { Seviyelerdedir }\end{array}$} & Kesinlikle Katılmıyorum & 12 & 8,8 \\
\hline & Katılmiyorum & 27 & 19,7 \\
\hline & Kararsızım & 32 & 23,4 \\
\hline & Katıliyorum & 39 & 28,5 \\
\hline & Kesinlikle Katıliyorum & 27 & 19,7 \\
\hline \multirow{5}{*}{$\begin{array}{l}\text { Dünya Ortalamasının } \\
\text { Üstündeyiz }\end{array}$} & Kesinlikle Katılmıyorum & 25 & 18,2 \\
\hline & Katılmiyorum & 52 & 38,0 \\
\hline & Kararsızım & 38 & 27,7 \\
\hline & Katıliyorum & 14 & 10,2 \\
\hline & Kesinlikle Katıliyorum & 8 & 5,8 \\
\hline Dünya İle Kıyaslandığında & Kesinlikle Katılmıyorum & 9 & 6,6 \\
\hline
\end{tabular}


Uşak Üniversitesi Sosyal Bilimler Dergisi

$2013,6 / 3$

Y. AKYÜZ

\begin{tabular}{|c|c|c|c|}
\hline \multirow{4}{*}{$\begin{array}{l}\text { Eğitim Yönünden } \\
\text { Eksikliklerimiz Var }\end{array}$} & Katılmiyorum & 6 & 4,4 \\
\hline & Kararsızım & 18 & 13,1 \\
\hline & Kat1liyorum & 59 & 43,1 \\
\hline & Kesinlikle Katıliyorum & 45 & 32,8 \\
\hline \multirow{5}{*}{$\begin{array}{l}\text { Dünyaya Göre Türkiye Orta } \\
\text { Sıralarda Yer Alıyor }\end{array}$} & Kesinlikle Katılmıyorum & 6 & 4,4 \\
\hline & Katılmiyorum & 19 & 13,9 \\
\hline & Kararsızım & 44 & 32,1 \\
\hline & Katılıyorum & 55 & 40,1 \\
\hline & Kesinlikle Katılıyorum & 13 & 9,5 \\
\hline \multirow{5}{*}{$\begin{array}{l}\text { Türklerde Girişimcilik Ruhu } \\
\text { Daha Fazladır }\end{array}$} & Kesinlikle Katılmıyorum & 7 & 5,1 \\
\hline & Katılmiyorum & 21 & 15,3 \\
\hline & Kararsızım & 37 & 27,0 \\
\hline & Katıliyorum & 48 & 35,0 \\
\hline & Kesinlikle Katıliyorum & 24 & 17,5 \\
\hline \multirow[t]{5}{*}{ Kültür Farklılığımız Vardır } & Kesinlikle Katılmıyorum & 6 & 4,4 \\
\hline & Katılmiyorum & 5 & 3,6 \\
\hline & Kararsızım & 22 & 16,1 \\
\hline & Katıliyorum & 59 & 43,1 \\
\hline & Kesinlikle Katılıyorum & 45 & 32,8 \\
\hline \multirow{5}{*}{$\begin{array}{l}\text { Sermaye ve Teşvik } \\
\text { Bakımından Dünyanın } \\
\text { Gerisindeyiz }\end{array}$} & Kesinlikle Katılmıyorum & & \\
\hline & Katılmiyorum & 12 & 8,8 \\
\hline & Kararsızım & 34 & 24,8 \\
\hline & Katıliyorum & 56 & 40,9 \\
\hline & Kesinlikle Katılıyorum & 35 & 25,5 \\
\hline \multirow{5}{*}{$\begin{array}{l}\text { Kültürel Yapıları Çok } \\
\text { Farklıdır ve Yaşam Koşulları } \\
\text { Bizden Çok İyidir }\end{array}$} & Kesinlikle Katılmıyorum & 3 & 2,2 \\
\hline & Katılmıyorum & 19 & 13,9 \\
\hline & Kararsizım & 20 & 14,6 \\
\hline & Katılıyorum & 55 & 40,1 \\
\hline & Kesinlikle Katılıyorum & 40 & 29,2 \\
\hline \multirow{4}{*}{$\begin{array}{l}\text { Ticari Ahlak Yönünden } \\
\text { Daha Gerideyiz }\end{array}$} & Kesinlikle Katılmıyorum & 29 & 21,2 \\
\hline & Katılmıyorum & 24 & 17,5 \\
\hline & Kararsızım & 40 & 29,2 \\
\hline & Katıliyorum & 31 & 22,6 \\
\hline
\end{tabular}


Uşak Üniversitesi Sosyal Bilimler Dergisi

$2013,6 / 3$

Y. AKYÜZ

\begin{abstract}
\begin{tabular}{|l|l|l|l|}
\hline & Kesinlikle Katıliyorum & 13 & 9,5 \\
\hline
\end{tabular}
Öğrencilerin \%71'lik kısmı KOSGEB hizmetlerine internetten ulaşabildiklerini belirtmişlerdir. KOSGEB ile ilgili sorular Tablo 5'te görülmektedir. KOSGEB Hizmetlerinden Yararlanmak İstiyorum diyenlerin oranı $\% 64.2 \mathrm{dir}$
\end{abstract}

Tablo 5: KOSGEB Desteklerine Bakış Açıları

\begin{tabular}{|c|c|c|c|}
\hline & & Frekans & Yüzde \\
\hline \multirow{5}{*}{$\begin{array}{l}\text { Eğitim İhtiyaçlarının } \\
\text { Karşılanması Yeterlidir }\end{array}$} & Kesinlikle Katılmıyorum & 17 & 12,4 \\
\hline & Katılmiyorum & 38 & 27,7 \\
\hline & Kararsızım & 44 & 32,1 \\
\hline & Katıliyorum & 29 & 21,2 \\
\hline & Kesinlikle Katılıyorum & 9 & 6,6 \\
\hline \multirow{5}{*}{$\begin{array}{l}\text { Girişimciliği Geliştirme } \\
\text { Faaliyetleri Yeterlidir }\end{array}$} & Kesinlikle Katılmıyorum & 9 & 6,6 \\
\hline & Katılmiyorum & 42 & 30,7 \\
\hline & Kararsızım & 38 & 27,7 \\
\hline & Katıliyorum & 38 & 27,7 \\
\hline & Kesinlikle Katıliyorum & 10 & 7,3 \\
\hline \multirow{5}{*}{$\begin{array}{l}\text { Kredi Ve Finansman } \\
\text { Destekleri Yeterlidir }\end{array}$} & Kesinlikle Katılmıyorum & 10 & 7,3 \\
\hline & Katılmiyorum & 30 & 21,9 \\
\hline & Kararsızım & 38 & 27,7 \\
\hline & Katıliyorum & 50 & 36,5 \\
\hline & Kesinlikle Katıliyorum & 9 & 6,6 \\
\hline \multirow{5}{*}{$\begin{array}{l}\text { Pazarlama ve Rekabet } \\
\text { Gücünün Geliştirilmesine } \\
\text { Yardımcı Olmaktadır }\end{array}$} & Kesinlikle Katılmıyorum & 6 & 4,4 \\
\hline & Katılmiyorum & 14 & 10,2 \\
\hline & Kararsızım & 39 & 28,5 \\
\hline & Katıliyorum & 65 & 47,4 \\
\hline & Kesinlikle Katıliyorum & 13 & 9,5 \\
\hline \multirow{5}{*}{$\begin{array}{l}\text { KOSGEB Hizmetlerine } \\
\text { İnternetten } \\
\text { Ulaşabilmektedir }\end{array}$} & Kesinlikle Katılmıyorum & 3 & 2,2 \\
\hline & Katılmiyorum & 6 & 4,4 \\
\hline & Kararsızım & 30 & 21,9 \\
\hline & Katılıyorum & 65 & 47,4 \\
\hline & Kesinlikle Katılıyorum & 33 & 24,1 \\
\hline
\end{tabular}


Uşak Üniversitesi Sosyal Bilimler Dergisi

$2013,6 / 3$

Y. AKYÜZ

\begin{tabular}{|c|c|c|c|}
\hline \multirow{5}{*}{$\begin{array}{l}\text { KOSGEB Kendini } \\
\text { Yeterince } \\
\text { Tanitabilmektedir }\end{array}$} & Kesinlikle Katılmıyorum & 11 & 8,0 \\
\hline & Katılmiyorum & 19 & 13,9 \\
\hline & Kararsızım & 35 & 25,5 \\
\hline & Katıliyorum & 51 & 37,2 \\
\hline & Kesinlikle Katıliyorum & 21 & 15,3 \\
\hline \multirow{5}{*}{$\begin{array}{l}\text { KOSGEB Hizmetlerinden } \\
\text { Yararlanmak İstiyorum }\end{array}$} & Kesinlikle Katılmıyorum & 5 & 3,6 \\
\hline & Katılmiyorum & 11 & 8,0 \\
\hline & Kararsızım & 33 & 24,1 \\
\hline & Katıliyorum & 35 & 25,5 \\
\hline & Kesinlikle Katıliyorum & 53 & 38,7 \\
\hline \multirow{5}{*}{$\begin{array}{l}\text { Kendime Ait Bir İş Planı } \\
\text { Hazırlayabilirim }\end{array}$} & Kesinlikle Katılmıyorum & 8 & 5,8 \\
\hline & Katılmıyorum & 12 & 8,8 \\
\hline & Kararsızım & 31 & 22,6 \\
\hline & Katıliyorum & 42 & 30,7 \\
\hline & Kesinlikle Katılıyorum & 44 & 32,1 \\
\hline \multirow{5}{*}{$\begin{array}{l}\text { KOSGEB Dışındaki } \\
\text { Destekler Hakkında Bilgim } \\
\text { Var }\end{array}$} & Kesinlikle Katılmıyorum & 27 & 19,7 \\
\hline & Katılmiyorum & 34 & 24,8 \\
\hline & Kararsızım & 26 & 19,0 \\
\hline & Katıliyorum & 35 & 25,5 \\
\hline & Kesinlikle Katılıyorum & 15 & 10,9 \\
\hline
\end{tabular}

\section{Sonuç ve Öneriler}

Ülke genelinde girişimciliğin gelişiminde en önemli faktörlerden biri de bu konuda verilen eğitimlerin yaygınlaştırılması ve kişilerin girişimcilik özelliklerinin geliştirilmesidir. Bu açıdan bakıldığında üniversitelerde okutulan girişimcilik eğitiminin dünyadaki ve Türkiye'deki mevcut durumunu ortaya koyma ihtiyacı ve üniversite öğrencilerinin mezuniyet sonrasında girişimci olmaları yönünde verilen eğitimlerin nasıl daha verimli hale getirileceğinin belirlenmesi önem kazanmaktadır.

Üniversitelerdeki eğitim, ülkemizin girişimci insan kaynaklarının yetiştirilmesinde önemli bir yere sahiptir. Üniversitelerde girişimcilik dersleri genelde işletmecilik bölümlerinde verilmektedir. Uşak Üniversitesi'nde girişimcilik dersinin sadece işletme programlarında değil 
tüm programlarda seçmeli ders olarak okutulması yerinde bir karar olmuştur. Bu dersin zorunlu olmasını sağlayacak şekilde çalışmalar yapılmalıdır. Bunun yanında Girişimcilik kültürünün oluşturulması için de, ilkokul çağından girişimcilik eğitimine başlamalı, yüksek öğrenim ve staj dönemlerinde de devam ettirilmelidir.

Girişimcilik alanında farklı kurum ve kuruluşlarca eğitim sürecinin farklı kademelerinde girişimcilik eğitimleri verilmektedir. Uşak Üniversitesi'nde de KOSGEB bağlantılı seçmeli Uygulamalı Girişimcilik Eğitimleri verilmektedir. Bu derslerin yürütüldüğü eğitim programlarında öncelikli olarak girişimci niteliklerini güçlendiren çevrenin geliştirilmesi, girişimcilik fikir fırsatlarının değerlendirilmesinin öğrencilerce algılanışının öğretilmesi amaçlanmaktadır.

$\mathrm{Bu}$ çalışmada yükseköğretim kurumları tarafından KOSGEB girişimcilik destek programı kapsamında ders alan Uşak üniversitesi öğrencilerinin KOSGEB desteklerine bakış açıları, girişimcilik eğilimleri ve girişimcilik özellikleri anket yöntemi kullanılarak elde edilen bilgiler ışığında değerlendirilmiştir. Ankete katılan öğrencilerin mezun olduktan sonra \%56,9'unun ise devlet memuru olmayı istediği görülmektedir. Üniversite öğrencilerinin çoğunluğu girişimci özelliklerinden, girişimciliğe yönlendiren özellikleri; yenilikçilik, liderlik, otokontrol, risk alma, bağımsız olma, kendine güven, iyimserlik ve başarı ihtiyacına katıldığını belirtmektedir. Öğrenciler dünyadaki girişimcilik ruhu ile Türkiye'deki girişimcilik ruhu kıyaslamasında \%75'lik kısmı dünya ile kıyaslandığında eğitim yönünden eksiklerin bulunduğu ve kültür farklılığının bulunduğunu belirtmiştir ve ayrıca öğrencilerin \%71'lik kısmı KOSGEB hizmetlerine internetten ulaşabildiklerini belirtmişlerdir. Ayrıca, KOSGEB Hizmetlerinden Yararlanmak İstiyorum diyenlerin oranı \% 64.2dir

Yapılacak bu ve benzeri çalışmalar ile KOBI'ler, büyük ölçekli işletmeler, üniversiteler ve meslek kuruluşları arasında işbirliğinin desteklenmesi, araştırma-geliştirme ile bilgi ve tecrübe paylaşımı geliştirilmelidir

Üniversitelerde, girişimcilik potansiyelini geliştirmeyi hedefleyen eğitimler yalnızca derslerle sınırlı kalmamalı, farklı girişimcilik etkinlikleriyle mevcut birikim daha da geliştirilmeye çalışılmalıdır.

\section{Kaynakça}

Akdemir, A. (2004). İşletmeciliğin Temel Bilgileri.: Tuğra Matbaacılık. Isparta 
Uşak Üniversitesi Sosyal Bilimler Dergisi

$2013,6 / 3$

Y. AKYÜZ

Akın, A., Zor, İ.,(2009). İşletmecilik Eğitiminin Bireyin Girişimci Niteliklerinin Geliştirilmesine Etkileri. “İş,Güç” Endüstri İlişkileri ve İnsan Kaynakları Dergisi,Cilt:11,Ocak, Sayı:1

Arıkan, S. (2004). Girişimcilik Temel Kavramlar ve Bazı Güncel Konular., Siyasal Kitabevi Ankara

Çalışkan Maya İ.; Uzman E., Işık H., (2012) Meslek Yüksekokulu Öğrencilerinin Girişimcilik Düzeylerini Farklı Kaynaklardan Algıladıkları Sosyal Desteğin Yordaması. Girişimcilik ve Kalkınma Dergisi, (7:1).

Çetinkaya Bozkurt, Ö. (2011). Dünyada ve Türkiye'de Girişimcilik Eğitimi: Başarılı Girişimciler ve Öğretim Üyelerinden Öneriler Detay Yayıncılık Ankara

Filiz, A. Çalışma Hayatında Değişim ve Girişimcilik, http://www.biymed.com/pages/makaleler/makale10.htmErişim: 15.08.2013.

Havinal, V. (2009). Management and Entrepreneurship, New Age International Publishers, New Delhi.

Hiscock, J.,Berthelot, S., Hessian, S., Darren, S. (2004). “Entrepreneurship In Atlantic Canadian University Environments," The Atlantic Canadian Universities Entrepreneurship Consortium, Acadia Centrefor Small Business and Entrepreneurship, Nova Scotia.

Huber, L.Rosendahl, S.,Randolph, P., Mirjam, V., (2012), TheEffect of Early Entrepreneurship Education: Evidencefrom a Randomized Field Experiment, IZA Discussion Paper, No 6512.

Kalaycı, Ş. (2010). SPSS Uygulamalı Çok Değişkenli İstatistik Teknikleri 5.Baskı, Asil Yayıncılık, Ankara

www.kosgeb.gov.tr/Pages/UI/Destekler.aspx?ref=8Erişim Tarihi:20.08.2013

Korkmaz, S. (2000). Girişimcilik ve Üniversite Öğrencilerinin Girişimcilik Özelliklerinin Belirlenmesine Yönelik Bir Araştırma. Hacettepe Üniversitesi İ̈̈BF Dergisi, 18(1), s.163-180.

Koh, HianChye (1996). "Testing Hypotheses of Entrepreneurial Characteristics: A study of Hong Kong MBA Students", Journal of Managerial Psychology, C.11, S.3, s. 12-25.

Klofsten, M. (2000). "Training Entrepreneurship at Universities: a Swedish Case", Journal of European Industrial Training 24 (6), s.337-344.

Leino, Jaana S.,Ruskavaara, E., Ikavalko, M., Mattila, J., vd(2009), Teachers as Learners Promoting Entreprenuership Education, The 20th 
Biannual NFF Conference, Turku/Abo, Finland, August 19-21, pp. 114.

Mueller, S. and Thomas, A.S. (2000). Culture and Entrepreneurial Potential: A Nine Country Study of Locus Control and Innovativeness. Journal of Business Venturing, 16, 52-62.

Müftüğlu, T. ve Durukan T. (2004). Girişimcilik ve KOBI'ler. Ankara:Gazi Kitabevi.

Öktem, M.K.; Aydın, M., Ekinci, S., (2007).Sosyo-Ekonomi Dergisi, Ocak Haziran 2007-1, ss. 48-76.

SeçkınHalaç, D., Bulut Ç., (2012). “Entrepreneurial Education at Universities: A Conceptual Framework"Journal of Entrepreneurship and Development $(7: 1)$

Tağraf, H, Halis, M., (2008). Üniversitelerdeki Girişimcilik Eğitiminin Öz Yetkinlik Algısı Üzerindeki Etkisi: Bir Araştırma. Girişimcilik ve Kalkınma Dergisi, Cilt 3, Sayı 2, ss. 91-111.

Tekin, M. (2009). Hayallerin Gerçeğe Dönüşümü Girişimcilik, Yenilenmiş 5. Baskı, Konya: Günay Ofset Matbaacılık.

Uygun, M., Mete, S., Güner, E.,(2012).Genç Girişimci Adayların Girişimcilik Eğilimi Ve Girişimcilik Özellikleri Arasındaki İlişkiler. Organizasyon Ve Yönetim Bilimleri Dergisi ,Cilt 4, Sayı 2,s.145-148.

Wilson, K., (2008).European Foundation for Entrepreneurship Research, OECD, Enterepreneurship and Higher Education, Chapter 5.

Yelkikalan, N., Akatay, A., Yıldırım, H., vd... (2010). KMÜ Sosyal ve Ekonomik Araştırmalar Dergisi, 12 (19), ss. 51-59.

Yılmaz E., Sünbül A.M. (2009) .Üniversite Öğrencilerine Yönelik Girişimcilik Ölçeğinin Geliştirilmesi Selçuk Üniversitesi Sosyal Bilimler Enstitüsü Dergisi , s.21

Yurtseven, H. Rıdvan, (2007). Girişimcilik Küçük Bir İşletme Kurmak ve Yönetmek Detay Yayıncılık, Ankara 